Journal of Engineering Sciences, Assiut University, Vol. 36, No. 2, pp. 357-369, March 2008

\title{
CRITICAL EVALUATION OF ASPHALT CONCRETE MIXES CONTAINING GRANULAR VOLCANIC ASH MATERIAL
}

\author{
Jamil A. Naji \\ Civil Engineering Department, Faculty of Engineering, Sana'a University, \\ P.O. Box 14166, Sana'a, Yemen \\ Email: jamil.abdulrabb@gmail.com
}

(Received December 25, 2007 Accepted January 17, 2008)

Granular volcanic ash material is spread over considerable parts of Yemen, including urban and suburban areas. Due to the inferior properties of this material in its natural state, it can not be used as a foundation layer either for roads or buildings. However, when improved it can be used in different applications. A recent study by the author has indicated that using granular volcanic ash as a partial replacement of conventional basalt aggregate in hot asphalt concrete mixes is technically feasible. All conventional criteria requirements suggested by Marshal Mix Design Method for hot asphalt concrete mix design were achieved with samples at different levels of granular volcanic ash content.

In this paper, further evaluation was performed to provide critical evaluation of some important mix characteristics. Samples, at different volcanic ash content, were prepared at optimum asphalt content and subjected to different advanced tests. These include dynamic creep, modulus of resilient, fatigue and permanent deformation tests. Results indicated that mixes containing volcanic ash aggregate had performed well in terms of creep and permanent deformation. However, improvements in fatigue life and in modulus of resilience were observed at volcanic ash contents up to $10 \%$ and $20 \%$, respectively. Further investigation is recommended to find ways for improving the properties of volcanic ash material so that the negative trends in fatigue life and modulus of resilience can be dealt with at higher volcanic ash content.

KEYWORDS: granular volcanic ash, hot asphalt concrete mixes, fatigue, permanent deformation, rutting, dynamic creep, modulus of resilience.

\section{INTRODUCTION}

Road construction in Yemen is growing at a substantial rate. A significant part of the country's Gross National Product (GNP) goes to road construction. The percentage of government investment on rural road building of the total annual investment plan has risen from $12.5 \%$ in 1997 to more than $23 \%$ in 2005. So far, construction of about $8000 \mathrm{~km}$ of two-way two-lane rural roads has almost been completed. Major portion of these roads are arterials connecting the main cities in the country.

The use of conventional crushed aggregate materials in pavement layers can be considered quite uneconomical and unwarranted due to the availability of other sources 
of materials. Using the locally available low-cost material is among the requirements to minimize the construction costs. Attempts should be made to explore the utilization of other low-cost sources of materials in the most effective manner for construction of roads.

In many parts of Yemen, surface geology is dominated by outcrops of Quaternary Volcanics. Figure 1 shows a map of the main sites of granular volcanic ash, with surface area estimated to be $17,000 \mathrm{~km}^{2}$ (Manetti P. et al 1991). Many sites of volcanic ash are located in urban and suburban areas. So far, this material is not utilized in for engineering purposes. Such material can be considered as one of the alternative sources that can be used in road building due to its availability in many locations in large quantities and in a free of charge cost.

The natural granular volcanic ash material has different inferior properties. Some of these are low density, non-cohesive structure, relatively high percentage of voids, and other undesirable properties. These properties make it undesirable foundation material either for roads or buildings. Therefore, it is considered as undesirable/waste material. When volcanic ash is encountered in construction sites, the common practice is to replace it by better material and transport the removed material to landfill sites. Such solution is uneconomical and the amount of hauled materials is increasing with time which necessitates regular allocation of new sites. The situation in some urban and suburban areas is might become an environmental issue due to the large amount of such hauled materials. It is clear that better management for such materials is needed. One possible way to resolving this problem is to recycle this waste material by improving its physical properties and utilizing it in the construction industry.

\section{LITERATURE REVIEW}

The use of volcanic aggregate in construction industry is very limited especially in roads construction. The literature survey have shown that a number of researches were performed to study the effect of using volcanic aggregate in concrete mixes, especially for producing light weight concrete and light weight masonry units. Results from their research showed that light weight concrete and masonry units having desired properties can be produced by using fine and coarse volcanic lightweight aggregate (Demirdag et al. 2007, Demirdag and Gunduz 2006, Hossain 2006, Alonso et al. 2001).

In the field of roads construction, previous studies (Naji, J. 2002 and Naji, J. \& Ali, S. 2002) have shown that the granular volcanic ash can be improved by stabilization with cement or lime and utilized in the construction of base and sub-base layers of roads. A recent study (Naji, J. 2007) has indicated the possibility of using granular volcanic ash material as a partial replacement of conventional crushed basalt aggregate in the construction of asphalt concrete layer. Results from that study showed that mixes, at granular volcanic ash content up to $20 \%$, have met all Marshall Criteria given in the Asphalt Institute Manual Series MS-2 (Asphalt Institute 1997). These include stability, flow, voids in mineral aggregate (VMA) and voids filled with asphalt (VFA). However, the literature review has revealed that evaluation criteria using conventional procedures, such as Marshall Criteria, are not sufficient to provide critical evaluation of paving mixes. Therefore, the use of more advanced paving mix tests is 
necessary to identify significant mix characteristics. These include creep resistance, dynamic modulus, fatigue life and permanent deformation (Al Kadi, A. N., 2002).

\section{RESEARCH OBJECTIVES}

The main objective of this study is to use advanced criteria procedures to evaluate some significant characteristics of asphalt concrete mixes that contain granular volcanic ash. These characteristics are creep resistance, modulus of resilience, fatigue life and permanent deformation. Another objective is to investigate optimum content of granular volcanic ash in asphalt concrete mixes.

\section{MATERIALS AND WORK PROGRAM}

Current literature review revealed that asphalt aggregate mixture is complex and considerable part of present knowledge is empirical in nature. Therefore, laboratory tests are the suitable solution to evaluate the engineering properties of the raw materials and mixes and to study the effect of granular volcanic ash material that might have an effect on the strength and other engineering properties of mixes. In order to achieve the objective of this study, experimental program similar to that depicted in Figure 2 was adopted.

The work program was divided into four phases. In phase I built-in collection and characterization of asphalt, basalt aggregates, mineral filler and granular volcanic ash material were performed. Asphalt samples were collected from the asphalt cementproducing refinery in Aden. Physical evaluation of the collected asphalt samples was conducted and results are shown in Table 1. The basalt aggregate used for the laboratory work was a crushed basalt aggregate obtained from one of the main source available in Sana'a area. The physical properties of the basalt aggregate are presented in Table 2.

The selected aggregate gradation was in accordance with the Asphalt Institute recommended gradation, nominal maximum size $19 \mathrm{~mm}$, see Figure 3. The mineral filler used was dust obtained during the screening and crushing of basalt aggregate. This filler is commonly used in Yemen. The basic properties of this material are also shown in Table 2.

The granular volcanic ash materials were collected from the vicinity of Sana'a city and subjected to a series of tests. Table 3 shows the physical properties of this material. While Table 4 shows the chemical composition of volcanic ash material used. In this study, four levels of volcanic ash content were used as a partial replacement of basalt aggregate; namely, $0 \%, 10 \%, 20 \%$ and $30 \%$ of total weight of mixture.

In phase II, four asphalt concrete mixes were investigated. The first mix was an asphalt concrete mix where all the used aggregates were basalt. Since basalt is the aggregate type which is usually used in most regions of Yemen, this mix was considered as the reference mix. In the second, third and fourth mixes, $10 \%, 20 \%$ and $30 \%$ of basalt aggregate were replaced by granular volcanic ash. Marshall Mix design procedure (ASTM D1559 - AASHTO T254), currently adopted procedure in Yemen for asphalt concrete mix design, was used to determine the optimum asphalt contents 
(OAC) of all sample mixes. The OAC were selected to produce $4 \%$ air voids. At the obtained OAC, samples were prepared for phase III.

In Phase III, advanced tests including dynamic creep, modulus of resilience, fatigue and rutting were performed on the samples prepared at OAC. The effectiveness of using volcanic ash material, as a partial replacement of basalt aggregate, was judged by the improvement in creep behaviour, modulus of resilience, fatigue life and the resistance to permanent deformation. In Phase IV, results were analysed and conclusions and recommendations were drawn.

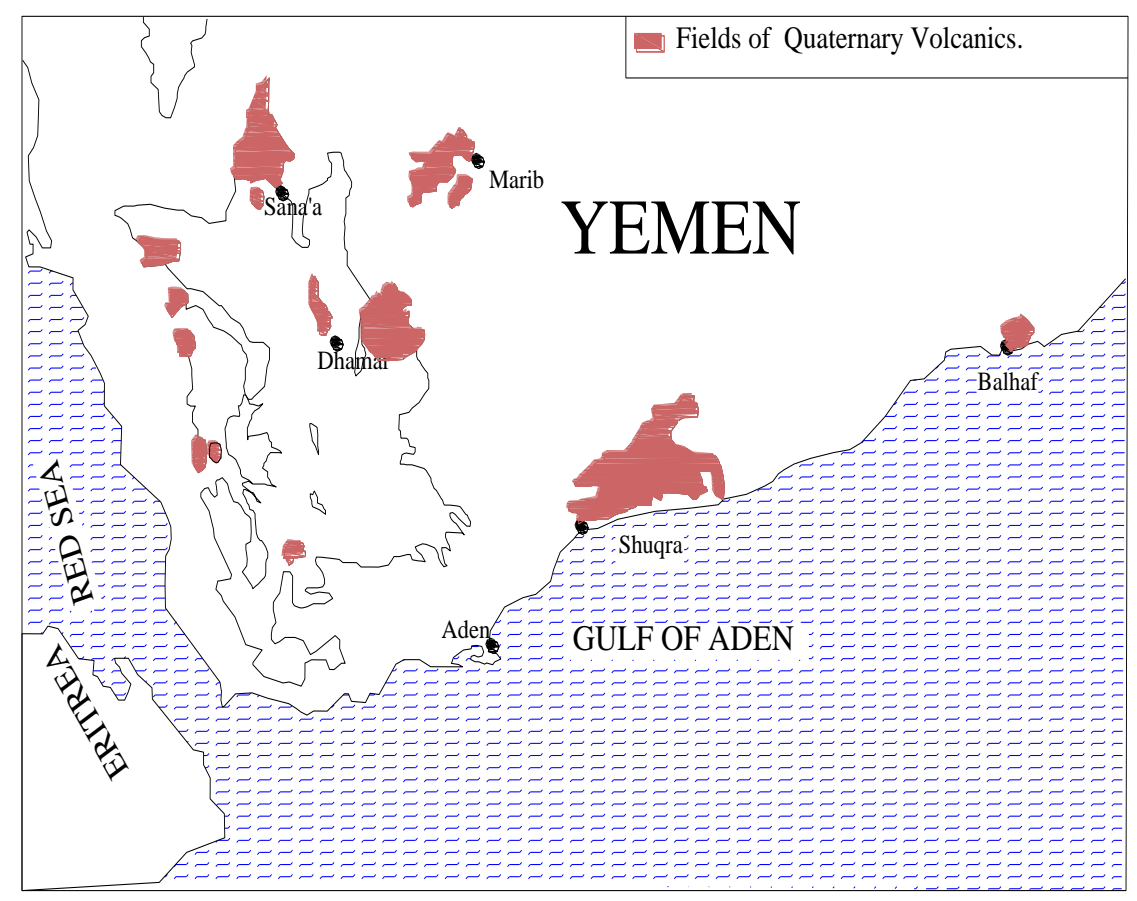

Figure 1: Main locations of Quaternary volcanic ash in Yemen 


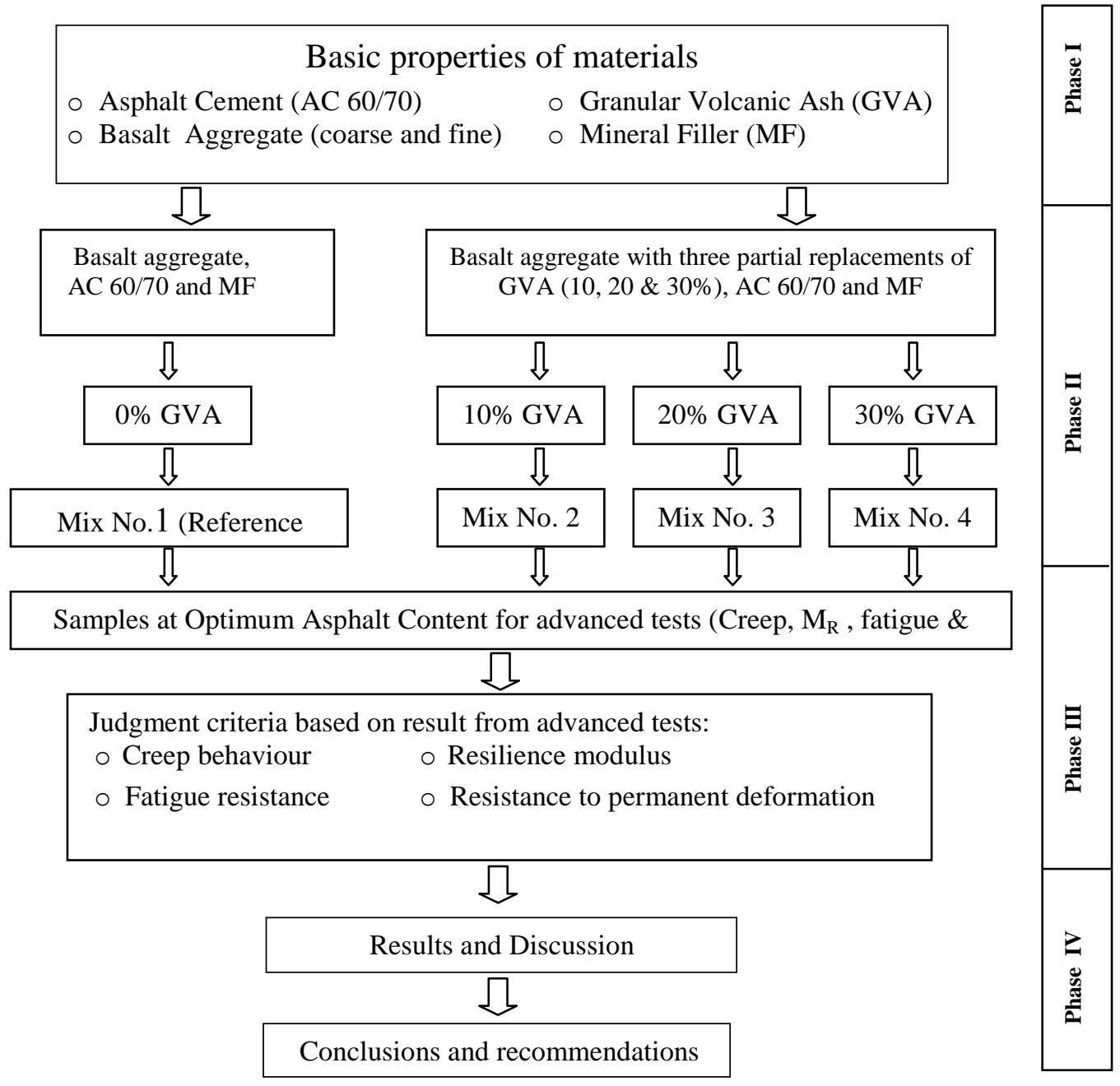

Figure 2: Flow chart of experimental design

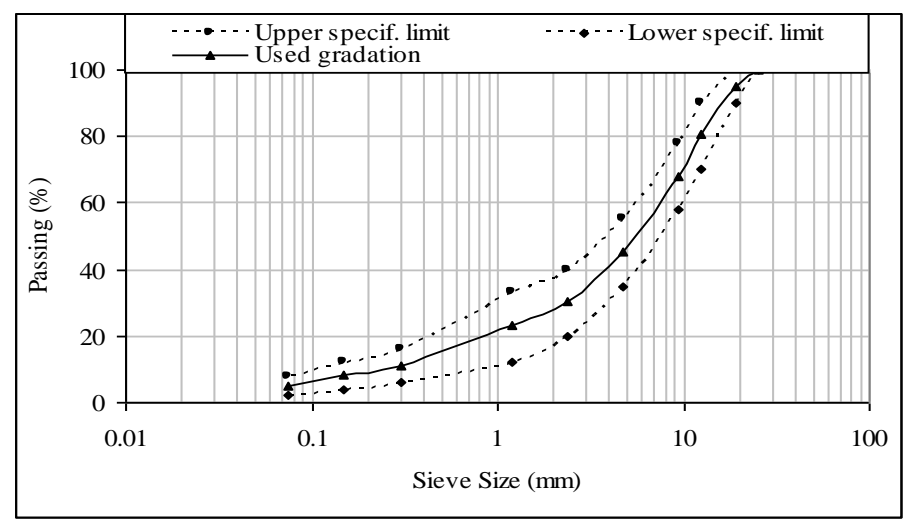

Table 1: Basic properties of asphalt

\begin{tabular}{ll}
\hline Property & Value \\
\hline Penetration & $60 / 70$ \\
Specific gravity & 1.03 \\
Ductility cm & 150 \\
\hline
\end{tabular}

Figure 3: Gradation used 
Table 2: Basic properties of basalt aggregates and mineral filler

\begin{tabular}{|c|c|c|c|}
\hline \multirow[t]{2}{*}{ Property } & $\begin{array}{l}\text { Basalt Coarse } \\
\text { Agg. }\end{array}$ & Basalt Fine Agg. & $\begin{array}{l}\text { Mineral } \\
\text { Filler }\end{array}$ \\
\hline & Value & Value & Value \\
\hline Specific Gravity & 2.789 & 2.88 & 2.965 \\
\hline Absorption \% & 4.25 & - & - \\
\hline Impact Value \% & 5 & - & - \\
\hline $\begin{array}{l}\text { Abrasion Loss \% (Los } \\
\text { Angeles) }\end{array}$ & 18 & - & - \\
\hline
\end{tabular}

Table 3: Volcanic ash properties

\begin{tabular}{lc}
\hline Property & Value \\
\hline Specific Gravity & 1.98 \\
Liquid Limit & N.P. \\
Plasticity Index & N.P. \\
Organic matters & Nil \\
Passing \# 200 sieve & Non \\
Clay content & Non \\
AASHTO & A-1-a \\
classification & \\
Unified classification & GW \\
Coefficient of & 5.6 \\
Uniformity & \\
Coefficient of & 1.15 \\
Curvature & \\
Wearing percentage $\%$ & 27 \\
Sulphate content & Nil \\
\hline
\end{tabular}

Table 4: Chemical composition of volcanic ash

\begin{tabular}{lc}
\hline Component & Percentage \\
\hline $\mathrm{SiO} 2$ & 47.2 \\
$\mathrm{Al} 2 \mathrm{O} 3$ & 19.2 \\
$\mathrm{Fe} 2 \mathrm{O} 3$ & 11.6 \\
$\mathrm{CaO}$ & 8.1 \\
$\mathrm{Na} 2 \mathrm{O}$ & 4.8 \\
$\mathrm{MgO}$ & 4.2 \\
$\mathrm{TiO} 2$ & 1.7 \\
$\mathrm{~K} 2 \mathrm{O}$ & 1.2 \\
$\mathrm{MnO}$ & 0.8 \\
$\mathrm{P} 2 \mathrm{O} 5$ & 0.5 \\
$\mathrm{LiO}$ & 0.5 \\
\hline Total & 99.8 \\
\hline
\end{tabular}

Source: Hosain, M. Fara (1999)

\section{RESULTS AND DISCUSSION}

Results obtained from this study were divided into four sets which included results related to creep behaviour, results related to modulus of resilience, results related to fatigue resistance and results related to permanent deformation (rutting).

\section{a) Dynamic Creep Test}

Creep test was performed according to the protocol developed by NCHRP 9-19 SUPERPAVE Models, Draft Test Method W2 (WitcWitczak, M. 2001). The test was performed at same temperature conditions mentioned in the previous tests.

The applied stress on the specimen was a feed back haversine in shape. The loading pulse repetition of 1000 milliseconds $-1 \mathrm{~Hz}$ frequency- and pulse width of 100 milliseconds was used. The deviator stress during each loading pulse was $69 \mathrm{kPa}$, and the contact stress that was applied so that the vertical loading shaft does not lift off the test specimen during the rest period was $11 \mathrm{kPa}$. The testing was continued until the maximum axial strain limit reached 10000 micro-strains, or until 10000 cycles, whichever occurred first. 
Figure 4 shows typical relationship between number of cycles and the percentage of accumulated strain for four tested samples at different volcanic ash content. As the volcanic ash content increases the accumulated strain decreases. This implies that volcanic ash has improved the creep resistance of the asphalt concrete mixes and this might be attributed to the rough texture properties of volcanic ash particles which bring about improvement in the cohesive properties of the mix. The improvement in creep properties becomes less significant at volcanic ash content exceeding $20 \%$ and this might be attributed to the increase in the fine particles of volcanic ash, at higher percentages, which have non plastic properties and, therefore, reduce the cohesive properties.

Statistical analysis was performed to determine whether the differences existed among the mean creep values, at different volcanic ash contents, are statistically significant. The Statistical Package for Social Science SPSS software was used for this purpose. An Analysis of Variance test ANOVA was conducted at 0.05 significance level (S.L.). The appropriate procedure for testing the differences among treatment means (i.e. creep stiffness means at different level of volcanic ash $\mu$ 's) is to check the following hypothesis (Montgomery, D. C. 1991):

$$
\begin{aligned}
& H_{0}: \mu_{1}=\mu_{2}=\ldots \ldots \ldots=\mu_{n} \\
& H_{1}: \text { at least two means are not equal }
\end{aligned}
$$

Statistical results from ANOVA analysis are presented in Table 5. The results indicate that utilization of granular volcanic ash has significantly influenced the creep behaviour of the mixes at the studied S.L. In other words, the creep stiffness mean values are significantly different form each other and these differences are due to the different percentages of volcanic ash used.

\section{b) Resilient Modulus Test (( $\left.\mathbf{M}_{\mathbf{R}}\right)$.}

Resilient modulus is the most important variable that is used in the mechanistic design of pavement structures. It is the measure of pavement response in terms of dynamic stresses and corresponding strains. The modulus of resilience is directly related to the load spreading ability of a material and describes the relationship between stress and strain and shows how much a material will deform under load. It varies with temperature and speed/time with which load is applied due to its visco-elastic behaviour (Kamal, M.A. et al 2005 and Asi, I. \& Assa'ad, A. 2005).

Eight samples from each mix were tested at two positions under the diametral resilient modulus $\left(\mathrm{M}_{\mathrm{R}}\right)$ test at $25 \pm 1^{\circ} \mathrm{C}$. The samples were tested at pulse width of 100 millisecond and pulse repetition of 1000 millisecond. Figure 5 shows typical results of the obtained $M_{R}$ values for different mixes. The results indicate that using up to $20 \%$ of granular volcanic ash in the mixes has improved the diametral resilient modulus. While the use of $30 \%$ granular volcanic ash has decreased the diametral resilient modulus. The rough surface texture of the granular volcanic ash particles which bring about improvement of the interlocking of the aggregate was the reason behind the increase in the $M_{R}$ values at the low volcanic ash contents. At higher volcanic ash contents, the effect of the lower strength of the granular volcanic ash was more influence than its rough texture, resulting in the decrease of the $M_{R}$ values. 
Statistical analysis was performed to study the significance of inclusion of granular volcanic ash in changing the $\mathrm{M}_{\mathrm{R}}$ values. ANOVA test was run at 0.05 level of significance. Results, Table 6, indicated significant difference in $M_{R}$ values due to the inclusion of granular volcanic ash in the mixes.

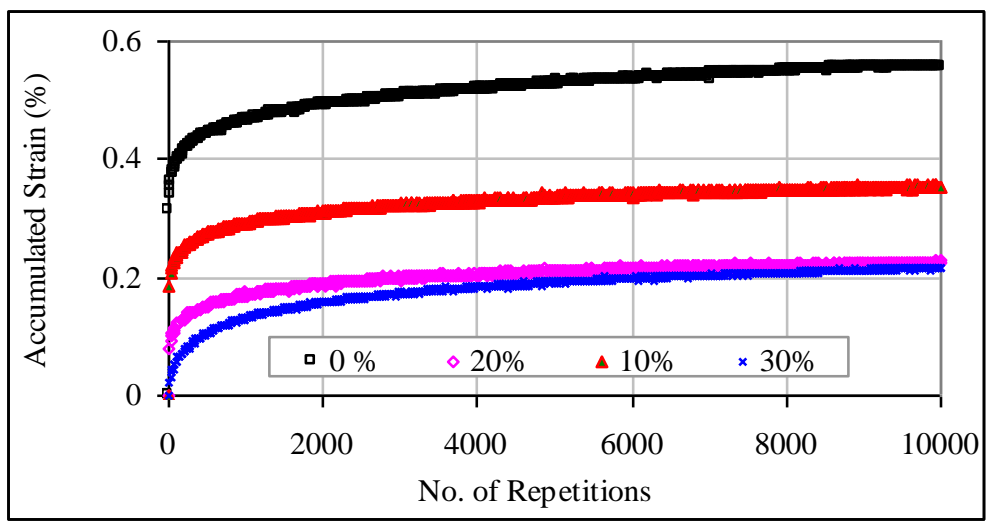

Figure 4: Effect of granular volcanic ash content on creep resistance.

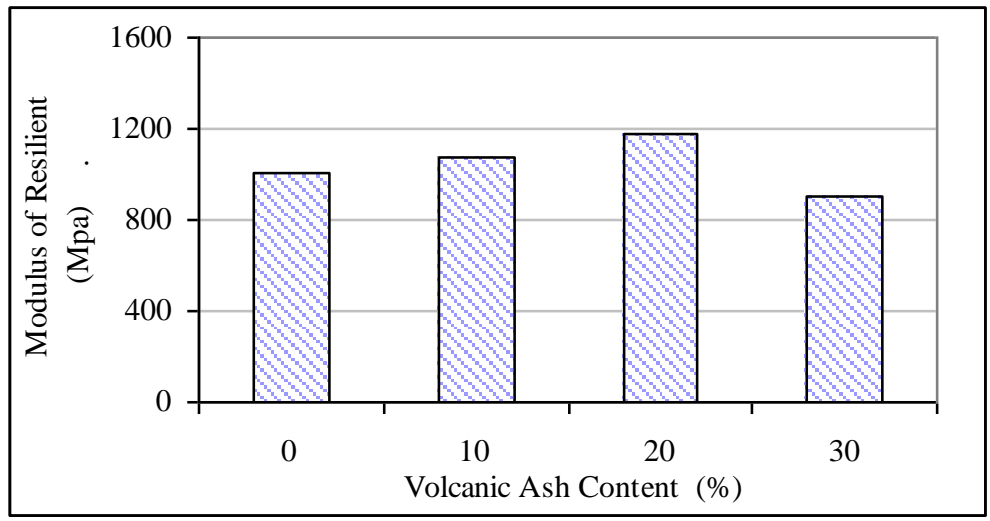

Figure 5: Effect of granular volcanic ash on modulus of resilience.

\section{c) Fatigue Resistance:}

The fatigue characteristic of the mixes was measured using diametral indirect tensile loading in controlled stress mode. The testing program utilized a Universal Testing Machine UTM with closed-loop system. In this system, haversine in shape load pulse at load frequency of $2 / 3 \mathrm{~Hz}(0.25 \mathrm{sec}$ loading and $1.25 \mathrm{sec}$ unloading times) was used. An environmental chamber capable of providing constant temperatures at $25 \pm 1^{\circ} \mathrm{C}$ was used to control temperature during the testing of samples. The specimen's skin and core temperatures during the test were monitored by two thermocouples which were inserted in a dummy specimen and located near the specimen under test. 
Samples were tested to determine the number of loading cycles required to fail the sample. To have a wide range of failure cycles, samples were tested at different initial tensile strain levels. At least six samples from each mix (two at each initial tensile strain level) were tested. Results are presented in Figure 6. Results indicate that fatigue life has improved by adding $10 \%$ volcanic ash but considerable decrease in fatigue life was noticed at high volcanic ash content. The reason behind the increase in fatigue life at $10 \%$ volcanic ash content might be due to the rough surface texture of the granular volcanic ash particles which resulted in an improvement in the interlocking of the aggregate. When the percentage of the granular volcanic ash increased, the lower strength of the granular volcanic ash was more effective than its rough texture. Thus, the optimum volcanic ash content that produced better fatigue life was found to be $10 \%$.

Statistical analysis using one way ANOVA indicates that the mean values of fatigue resistance, at different volcanic ash contents, are significantly different from each other at 5\% S.L.

\section{d) Permanent Deformation Performance:}

This test measures the relative performance of asphalt concrete against permanent deformation. This test was performed along with fatigue test and at the same conditions. Two vertical LVDT's were used to measure the vertical permanent deformation while running the fatigue tests. Figure 7 shows typical permanent deformation behaviour of samples tested at a repeated average stress of $149 \mathrm{kPa}$. Results indicate that mixes that contain volcanic ash have least rutting potential and as the volcanic ash content increases the permanent deformation decreases.

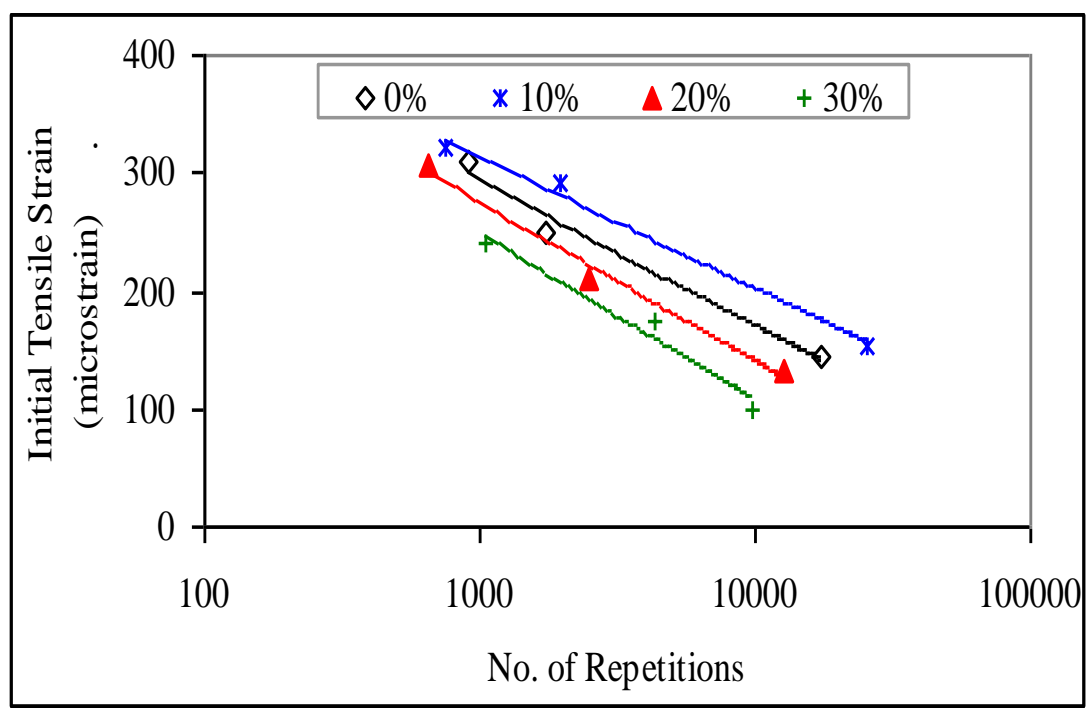

Figure 6: Effect of granular volcanic ash content on fatigue life. 


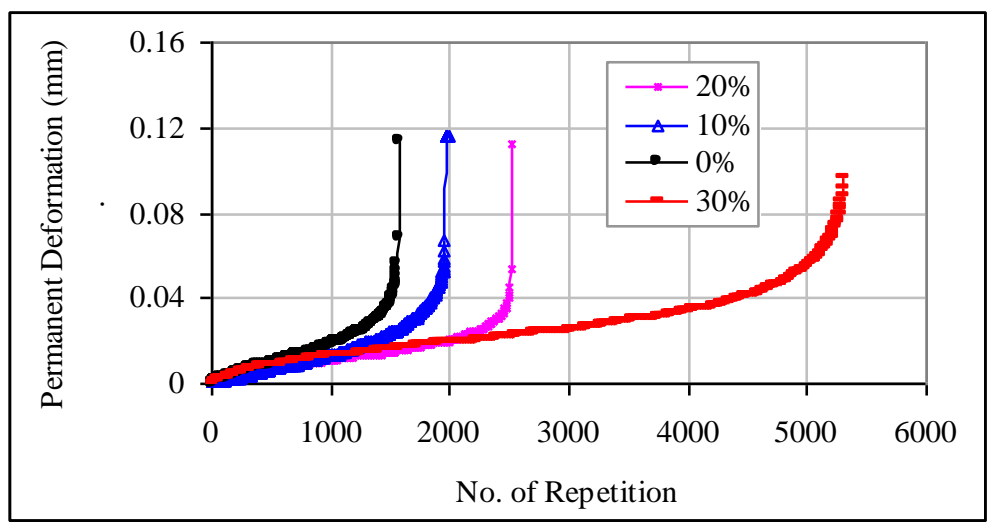

Figure 7: Effect of granular volcanic ash content on rutting.

Table 5: Analysis Of Variance (ANOVA) for the obtained creep results

\begin{tabular}{lccccc}
\hline Source of variation & Sum of Squares & df & Mean Square & F & Sig \\
\hline Between Group SSR & 0.441 & 3 & 0.147 & 923.106 & 0.000 \\
Within Group SSE & 0.003 & 20 & 0.000 & & \\
Total SST & 0.444 & 23 & & & \\
\hline
\end{tabular}

Table 6: Analysis Of Variance (ANOVA) for the obtained Resilient Modulus MR

\begin{tabular}{lrcccc}
\hline Source of Variation & Sum of Squares & df & Mean Square & F & Sig \\
\hline Between Group SSR & 22657929.438 & 3 & 7552643.146 & 31.283 & 0.000 \\
Within Group SSE & 6760097.063 & 28 & 241432.038 & & \\
Total SST & 29418026.500 & 31 & & & \\
\hline
\end{tabular}

\section{CONCLUSIONS AND RECOMMENDATIONS}

In previous study (Naji, J. 2007) asphalt concrete mixes containing granular volcanic ash were evaluated using Marshall conventional criteria procedures. Results from that study showed the possibility of using granular volcanic ash as a partial replacement of conventional basalt aggregate in asphalt concrete mixes. In this paper, more advanced tests were performed for critical evaluation of the mixes that contain volcanic ash. These included dynamic creep, resilient modulus, fatigue and rutting tests. Based on the results obtained the following conclusions and recommendations were drawn:

$\circ$ Using granular volcanic ash in asphalt concrete mixes has improved the creep and rutting properties of the mixes.

$\circ$ Mixes with $10 \%$ volcanic ash content showed improvement in fatigue life. However, at high volcanic ash content, exceeding the $10 \%$, reduction in fatigue life was noticed.

- There was an improvement in resilient modulus $\left(\mathrm{M}_{\mathrm{R}}\right)$ of mixes containing volcanic ash up to $20 \%$. The $\mathrm{M}_{\mathrm{R}}$ value started to decrease after that percentage.

$\circ$ Based on the pervious points, using volcanic ash in asphalt mixes should be limited to $10 \%$. However, more investigations are needed to improve the properties of the 
volcanic ash materials so that the negative trends in fatigue life and modulus of resilience can be solved at higher volcanic ash content. Such task can be considered in further research.

o Using volcanic ash in asphalt mixes, as a partial replacement of conventional aggregate, will serve two main purposes the better management of the (waste/undesirable) volcanic ash material and also to provide economical alternative of aggregate sources since it is a free of charge material.

\section{ACKNOWLEDGEMENTS:}

I would like to express my sincere gratitude and appreciation to Civil Engineering Department, Faculty of Engineering, Hashemite University, Jordon, for conducting the research's advanced tests in the Department Laboratories.

\section{REFERENCES}

1- Al Kadi, A. N. S. (2002) Effect of Oil Shale Ash on Fatigue Behaviour and Rutting of Flexible Pavement. MSc thesis, Jordan University of Science and Technology.

2- Alonso, E., Martínez, L., Martínez, W. and Villaseñor, L. (2001). "Mechanical Properties of Concrete Elaborated with Igneous Aggregates." Cement and Concrete Research, 32(2), 317-321.

3- Asi, Ibrahim and Assa'ad, Abdullah (2005) ASCE, "Effect of Jordanian Oil Shale Fly Ash on Asphalt Mixes." Journal of Materials in Civil Engineering, Vol. 17, issue 5 (pp. 553-559). Asphalt Institute (1997), Manual Series No. MS2, Sixth Edition.

4- Demirdag, S., Ugur, I. and Sarac, S. (2007). "The Effects of Cement/Fly Ash Ratios on the Volcanic Slag Aggregate Lightweight Concrete Masonry Units." Construction and Building Materials, In Press, Corrected Proof, Available online 12 July 2007.

5- Demirdag, S. and Gunduz, L. (2006). "Strength Properties of Volcanic Slag Aggregate Lightweight Concrete for High Performance Masonry Units." Construction and Building Materials, In Press, Corrected Proof, Available online 28 November 2006.

6- Hosain, M. Fara (1999) Geological Studies for the Quaternary Volcanics, Hamdan Volcanic Field- North of Sana'a, Sana'a University, Yemen (Arabic report).

7- Hossain, K. (2006). "High strength blended cement concrete incorporating volcanic ash: Performance at high temperatures." Cement and Concrete Composites, 28 (6), 535-545.

8- Kamal, M.A., Shazib, F. and Yasin, B. (2005) "Resilient Behaviour of Asphalt Concrete Under Repeated Loading \& Effects of Temperature." Journal of the Eastern Asia Society for Transportation Studies, Vol.6 ( pp. 1329-1343).

9- Manetti P., Capaldi G., Civetta L., Gasparon M. and Orsi G. (1991) Magmatism of the Eastern Red Sea Margin in the Northern Part of Yemen from Oligocene to Present.

10- Montgomery, D. C. (1991) Design and Analysis of Experiments. Third Edition, John Wiley \& Sons, New York. 
11- Naji, Jamil A. (2002) "The Use of Lime to Stabilize Granular Volcanic Ash Materials for Road Construction." Journal of Science \& Technology, Vol. 7 No2, University of Science and Technology, Yemen.

12- Naji, Jamil A. and Ali, S. A. (2000) Improvement of Volcanic Granular Ash Properties for Engineering Uses. Proceedings of the $8^{\text {th }}$ Arab Conference for Structural Engineering, Cairo.

13- Naji, Jamil A. (2007) Effect of using granular volcanic ash on the mechanical properties of hot mix asphalt, Journal of Science \& Technology, Vol. 12 No2, University of Science and Technology, Yemen.

14- WitcWitczak, M., Schwartz, C. and Von Quintus, H. (2001) NCHRP Project 9-19: Superpave support and performance models management. Interim Report, Federal Highway Administration and the National Cooperative Highway Research Program.

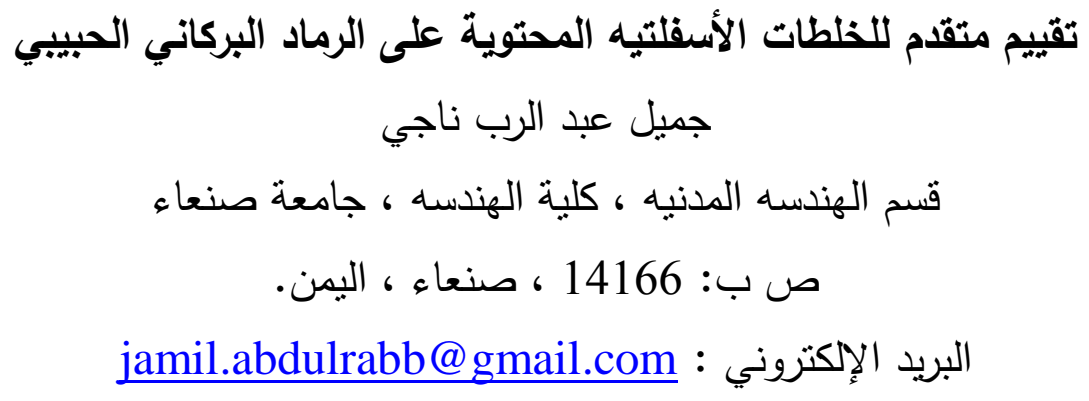

ينتشـر الرمـاد البركاني الحبيبي على أجزاء كبيرة مـن اليمن، بمـا في ذلك المنـاطق الحضـريه وشبه

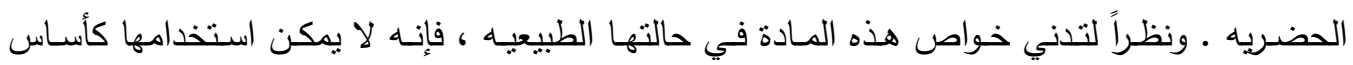
للمباني أو الطرق على حد سواء، لكن عندما يتم تحسين خواص هذه المادة فإنه يمكن استخدامها في تطبيقات عديدة.

بينت دراسة حديثة للمؤلف الى أن الإحلال الجزئي للأحجار البازلتيه برماد بركاني حبيبي في الخلطات

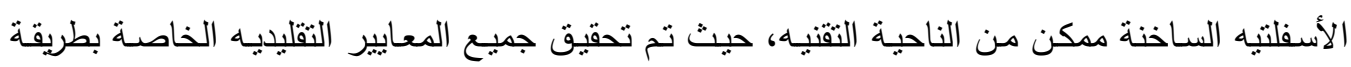
مارشال لتصميم الخلطات الأسفلتيه الساخنة عند محتويات مختلفه للرماد البركاني.

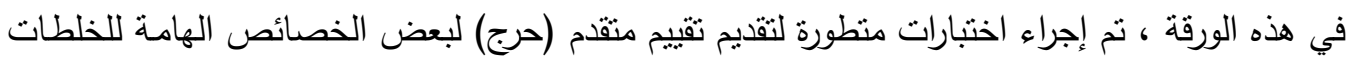
الأسفلتية الساخنة المحتوية على رماد بركاني، حيث تم تحضير عينات محتوية على نسب مختلفة من

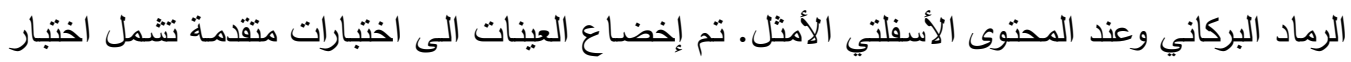

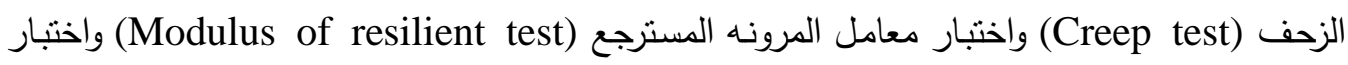

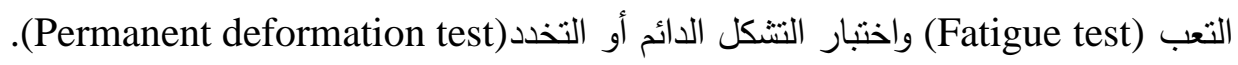
بينت النتائج الى أن كل الخلطات الأسفلتية المحتوية على رماد بركاني كان أدائها جيداً من حيث مقاومة

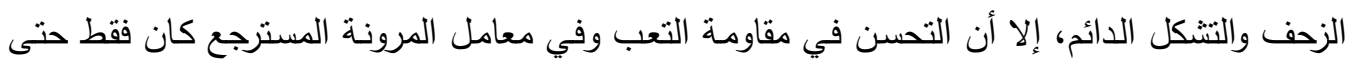


محتويات رماد بركاني 10\% و 20\% على التوالي. أن إجراء مزيد من الدراسات المسنقبلية موصى بها

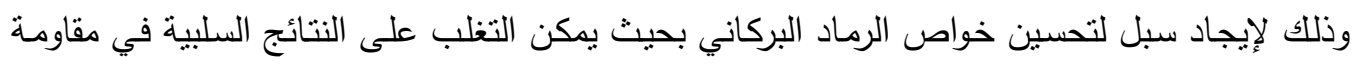

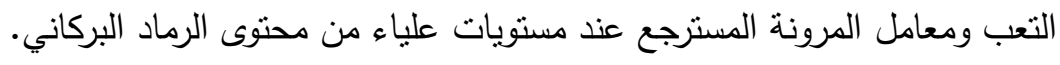

